ノ - r

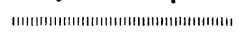

\title{
含鉊アクリル樹脂を使用した ${ }^{99 m} T c$ 遮蔽容器の試作 ${ }^{\dagger}$
}

\author{
市波義雄，阿部 均* \\ 国立東静病院アイントープ室 411 静岡県駿東郡清水町長沢762-1 \\ * 協和ガス化学工業株式会社 103 東京都中央区日本橋3-8-2 (新日本橋ビル 5 階) \\ 1979年 8 月 3 日受理
}

Key Words: visible technetium-99m vial shield, lead-loaded acryl

\section{1. はじめに}

アイソトープを用いた in vivo 検查に打けるテクネ チウム $\left({ }^{99 m} \mathrm{~T} \mathrm{c}\right)$ の利用は増加の一途である ${ }^{1)} 。{ }^{{ }^{99 m}} \mathrm{Tc}$ の利用は患者の被曝線量を減少させたが，1 回の使用 量が数 $\mathrm{mCi}$ から数十 $\mathrm{mCi}$ に及ぶため，それを取り扱 ら術者の手指の局所被曝が問題となっている2) 6)。

${ }^{99 m} \mathrm{~T} \mathrm{c}$ の標識操作（ラベリング）時に使用するバイ アルの遮蔽容器は鉛製のものが多く，溶液量が見えな いのが欠点である。また，細い含鉛ガラスのスリット をはめ込んだ労器もあるが見にくく，迅速なラベリン グや分注操作，溶液量の確認を行うさいの障害となっ ている。われわれは，含鉛アクリル樹脂を使用して， ${ }^{99 m} \mathrm{~T} c$ 取扱時に使用する透明な遮蔽容器を試作し, 遮 蔽効果, 使用状態について検討した。

\section{2. 容器および遮蔽能}

\section{$2 \cdot 1$ 容器の概要}

\section{$2 \cdot 1 \cdot 1$ 含鉛アクリル樹脂}

遮蔽容器の材料として使用した含鉛アクリル樹脂 (協和グラス, $\mathrm{XA}-\mathrm{H})^{7)}$ は透明であること，割れにく いこと，どのような形にでも加工できるなどの特長が ある。含鉛アクリルは重量比で30\%の鉛を含有してお り，わずかに着色 (淡褐色) している。使用した含鉛 アクリル樹脂の組成をTable 1 亿示す。

\section{$2 \cdot 1 \cdot 2$ 容器の大きさ}

$\dagger$ Visible ${ }^{99 m} \mathrm{Tc}$ Vial Shields Made of Lead-Loaded Acrylic Resin. Yosio ICHINAMI and Hitoshi ABE*: Division of Nuclear Medicine, National Tosei Hospital, 762-1 Simizu-cho, Suntogun, Sizuoka-ken 411, *Kyowa Gas Chem. Ind. Co. Ltd., Shin-nihonbashi Building, 8-2, Nihonbashi 3-chome, Chuo-ku, Tokyo 103.
Table 1 Element composition of the lead-loaded acrylic resin, Kyowaglas XA-H

\begin{tabular}{l|c|c|c|c}
\hline Element & $\mathrm{C}$ & $\mathrm{H}$ & $\mathrm{O}$ & $\mathrm{Pb}$ \\
\hline Content (\%) & 43.8 & 5.8 & 20.4 & 30.0 \\
\hline
\end{tabular}

含鉛アクリルの厚さ $25 \mathrm{~mm}$ （鉛当量 $1.14 \mathrm{~mm}$ ，以下 No. 1) と $30 \mathrm{~mm}$ (鉛当量 $1.36 \mathrm{~mm}$, 以下No. 2) の 2 種類試作した。容器の断面図をFig. 1 亿, 写真をFig. 2 亿示す。バイアル収納穴の下部にポリウレタンのク ッションを入れ，上部の蓋をねじ込むことによっで゚ イアルを固定する。蓋は注射器操作が行いやすいよう に厚さ $2 \mathrm{~mm}$ のステンレスに厚さ $2 \mathrm{~mm}$ の鉛板を重和 合わせて薄くした。蓋の中央の穴は, 注射器操作時に お仔る手指への被曝を少なくするために直径 $5 \mathrm{~mm}$ と 小さくした。

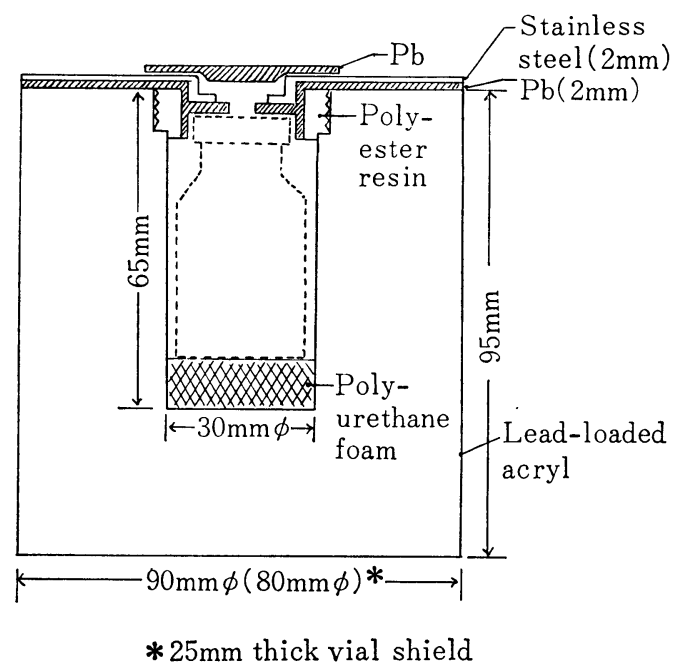

Fig. 1 Sketch of lead-loaded acrylic vial shield designed for $10 \mathrm{ml}$ vial. 


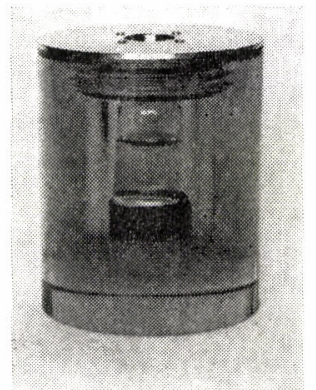

No. 1

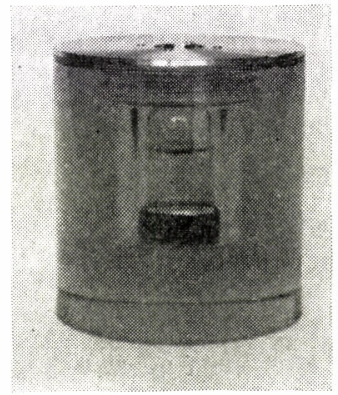

No. 2

Fig. 2 Photographs of the lead-loaded acrylic vial shields designed for $10 \mathrm{~m} l$ vial.

No. 1: $25 \mathrm{~mm}$ thick vial shield

No. 2: $30 \mathrm{~mm}$ thick vial shield

\section{$2 \cdot 2$ 遮蔽能測定}

\section{$2 \cdot 2 \cdot 1$ TLD による測定}

TLD 素子 $\left(\mathrm{Mg}_{2} \mathrm{SiO}_{4}\right)$ を用いて容器の遮蔽能を測定 した。測定器は極光製 TLD-1300を使用した。TLD 素子は, キュリメーター(アロカ製，IGC-2B）で放射 能量を測定した ${ }^{99 m} \mathrm{Tc}$ 溶液から $30 \mathrm{~cm}$ 離れた位置の測 定值と, ${ }^{99 m} \mathrm{~T} \mathrm{c}$ の照射線量率定数 $\left(0.076 \mathrm{Rh}^{-1} \mathrm{Ci}^{-1}\right.$ at $1 \mathrm{~m})^{8)}$ をいて計算した同位置にお的る計算値との差 が, JIS 規格9) の範囲内（土10\%）にはいる素子 30 本 を用いた。 ${ }^{99 m} \mathrm{~T} \mathrm{c}$ 溶液のはいったバイアルの側面と, バイアルを容器に収納した容器測面に TLD 素子を 5 本ずつ紙絆創高で固定し，60分間照射した。

\section{$2 \cdot 2 \cdot 2$ オートラジオグラフィ}

容器の遮蔽効果と, 遮蔽の均一性を観察するために オートラジオグラムを作成した。X線撮影用フィルム カセッテ（LH-II+RX）を垂直に立て， ${ }^{99 m} \mathrm{Tc}$ 溶液(5 $\mathrm{mCi} / 5 \mathrm{ml})$ のはいったバイアル ${ }^{99 m} \mathrm{Tc}$ 調整用 $10 \mathrm{ml}$, 日
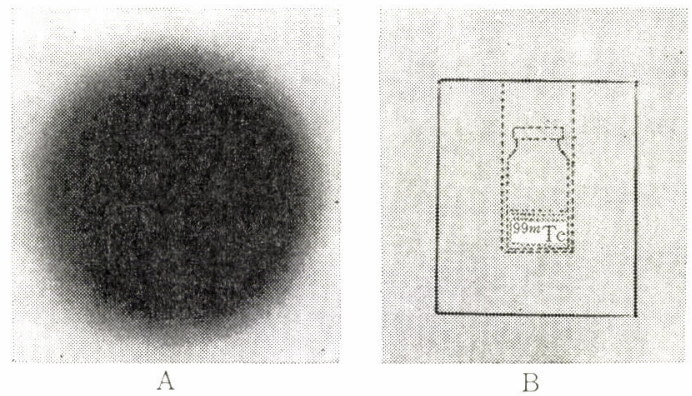

本メジフィジックス製）の側面を密着させた場合と， 容器に収納した容器側面を密着させた場合（容器を 90 度ずつ回転して 4 回行った)について，それぞれ 5 分 間ずつ露光した。

\section{3. 結果および考察}

3・1 TLD による測定

TLD 素子を用いて測定した容器の遮蔽能を Table 2 に示す。容器の遮蔽能はバイアルの大きさと, 溶液 量によって異なるが, No.1の容器で 1/131 1/184, No. 2 では 1/317 1/366 であった。遮蔽能がどれだけ 必要であるかが問題であるが，舍鉛アクリルの厚さが $5 \mathrm{~mm}$ 厚くなると遮蔽能が 2 倍となることを考光ると No. 2 の容器の汪らが適当ではないかと考える。

Table 2 Shielding capabilities ${ }^{1)}$ of acrylic vial shields of different thickness

\begin{tabular}{|c|c|c|c|c|c|}
\hline \multirow[b]{2}{*}{ Source } & \multirow{2}{*}{$\begin{array}{l}\text { Concen- } \\
\text { tration } \\
\left(\begin{array}{c}\mathrm{mCi} / \\
\mathrm{ml})\end{array}\right.\end{array}$} & \multirow{2}{*}{$\begin{array}{l}\text { Volu- } \\
\text { me } \\
(\mathrm{ml})\end{array}$} & \multicolumn{3}{|c|}{ Dose rates ${ }^{21}$ at the surface of } \\
\hline & & & $\begin{array}{c}\text { Vial } \\
(\mathrm{mR} / \mathrm{h})\end{array}$ & $\begin{array}{l}25 \mathrm{mmt} \\
\text { Vial } \\
\text { shield } \\
(\mathrm{mR} / \mathrm{h})\end{array}$ & $\begin{array}{l}30 \mathrm{mmt} \\
\text { Vial } \\
\text { shield } \\
(\mathrm{mR} / \mathrm{h}) \\
\end{array}$ \\
\hline \multirow{3}{*}{${ }^{99 m} \mathrm{Tc}$} & 1 & $3^{3)}$ & $2159 \pm 44$ & $11.7 \pm 1$ & $5.9 \pm 0.9$ \\
\hline & 1 & $5^{4)}$ & $2507 \pm 77$ & $17.5 \pm 1.9$ & $7.7 \pm 1$ \\
\hline & 1 & $10^{4)}$ & $4595 \pm 185$ & 535. & $14.5 \pm$ \\
\hline
\end{tabular}

1) Determined by TLD

2) Mean $\pm \mathrm{SD}$

3) Kept in $5 \mathrm{~m} l$ vial of Nihon Medi-physics.

4) Kept in $10 \mathrm{ml}$ vial of Nihon Medi-physics.

TLD 素子の測定値については, ${ }^{99 m} \mathrm{~T} \mathrm{c}$ の照射線量率 定数を用いた計算値 $25.19 \mathrm{mR}$ に対して, 使用した素 子 30 本の実測值は $27.0 \pm 1.6 \mathrm{mR}$ であり, 素子のバラ ツキを考慮に入れると良く一致 していると思われる。なお，測 定時には TLD 素子に対する室 内光の影響をさけるため暗幕を か汗，また照射時間中の ${ }^{99 m} \mathrm{Tc}$ の減衰を補正した。

$3 \cdot 2$ オートラジオグラフィ

X線写真用フィルムを用いて 作成した容器のオートラジオク゚ ラムをFig. 3 亿示す。Fig. 3 (A) はバィアルのままのものであ りフフィルムは広範囲に黒化し 
ている。Fig. 3 (B)(C)はNo. 1，No. 2 の容器に収納した とき（90度ずつ回転させたらちの各 1 枚）のものであ りいずれもフィルムは黒化せず, 容器の良い遮蔽能と 遮蔽の均一性を示している。

また，この容器の取扱いについては，バィアルが確 実に固定され，溶液量を見ながらラベリングや分注操 作が行えるため，操作は迅速に行えるが，少し大きい のが欠点かも知れない。しかし，片手でだれにでも持 てる程度の大きさである。容器の支持台があれば，手 で持って注射器操作を行う必要はないため, 容器支持 台の試作を検討中である。

\section{4. 結 論}

含鉛アクリル樹脂を使用して, ${ }^{99 m} \mathrm{~T} c$ のラベリング や分注操作時に使用する透明な遮蔽容器を試作し, 遮 蔽能を測定した結果はつぎのと抢りであり， ${ }^{99 m} \mathrm{Tc}$ 取 扱時の遮蔽容器として有用であると考える。

1）バィアルの溶液量を見ながら，ラベリングや分 注操作が行える。

2）バイアルが確実に固定されるため注射器操作が 容易である。

3）遮蔽能はバイアルの大きさと溶液量によって異 なるが，No. 1 の容器で 1/131〜1/184， No. 2 で 1/317 〜1/366である。

4) オートラジオグラムにより, 容器の均一な遮蔽
状態が観察できた。

本論文の要旨は, 日本放射線技術学会第31回静岡支 部総会（1979．6. 静岡）飞执いて発表した。また第34 回国立病院療養所総合医学会 (1979.10. 仙台) 飞演題 提出中である。

\section{文献}

1）中島智能：映像情報，11，(2）127（1979）

2）前越 久, 西沢邦秀, 他: Radioisotopes, 21, (5) 53 (1972)

3）山本千秋, 渡辺道子, 他 : ibid., 21, (5) 57 (1972)

4）金子昌生, 渡辺道子, 他：ibid., 21，（5） 60 (1972)

5）森 厚文, 小島一彦, 他：ibid., 27, (10） 35 (1978)

6）前越 久, 折戸武郎, 他： ibid., 27，(10） 38 (1978)

7) 阿部 均: 第34回日本放射線技術学会予稿集, 210 (1978)

8） 日本アイソトープ協会：Isotope news，(10) 31 (1978)

9）日本保安用品協会：フィルムパッジニュース, (44) 9 (1972) 